\title{
Rekonstruksi Defek 1/3 Medial Daun Telinga dengan Flap Dieffenbach
}

\author{
Irwandanon ${ }^{1}$, Al Hafiz ${ }^{2}$, Sukri Rahman ${ }^{2}$, Dolly Irfandy ${ }^{2}$
}

\begin{abstract}
Abstrak
Telinga dapat mengalami defek baik karena pasca pengangkatan tumor atau trauma. Berbagai teknik dapat digunakan untuk menutup defek pada telinga. Flap Dieffenbach merupakan salah satu teknik untuk merekonstruksi 1/3 medial daun telinga. Dilaporkan satu kasus seorang perempuan 48 tahun dengan keratosis seboroik pada 1/3 medial daun telinga yang kemudian dilakukan eksisi dan defek ditutup dengan flap Dieffenbach. Eksisi tumor daun telinga dapat menimbulkan defek pada telinga yang memerlukan rekonstruksi. Flap Dieffenbach dapat digunakan untuk menutup defek pada 1/3 medial daun telinga dengan hasil yang sangat baik dan memuaskan.
\end{abstract}

Kata kunci: defek telinga, eksisi, keratosis seboroik, flap Dieffenbach

\begin{abstract}
Ear defect can be caused by post excision tumors at the ear or trauma. Various technique can be used to close the defect at the ear. Flap Dieffenbach is one of the technique that can be used to close defect at 1/3 medial ear. Reported one case of a woman 48 years old with keratosis seborroik at medial third earlobe then performed excision and the defect was closed with Dieffenbach flap. Excision of tumor at the ear can cause defect at the ear that need reconstruction. Dieffenbach flap can be used to close the defect on the medial third of earlobe with great results and satisfactory.
\end{abstract}

Keywords: ear defects, excision, keratosis seborroik, Dieffenbach flap

Affiliasi penulis: 1. Pendidikan Dokter Spesialis THT-KL Fakultas Kedokteran Universitas Andalas, 2. Bagian THT-KL Fakultas Kedokteran Universitas Andalas,

Korespondensi: irwandanon, Irwandanon@yahoo.com Telp: 082285368517

\section{PENDAHULUAN}

Daun telinga atau pinna, merupakan salah satu bentuk paling kompleks pada manusia karena posisinya dan merupakan struktur berpasangan. Deformitas dari daun telinga sering menyebabkan gangguan psikologis yang lebih besar dibandingkan dengan ukuran defeknya. Bentuk normal dan proporsi telinga mudah dikenali tetapi sulit untuk merekonstruksi telinga tanpa teknik bedah yang baik dan apresiasi konfigurasi yang baik dari telinga normal. $^{1,2}$

Daun telinga memiliki topografi tiga dimensi yang kompleks yang terdiri dari kulit dan tulang rawan.
Kerangka tulang rawan terbuat dari tulang rawan fibroelastik terbungkus oleh kulit yang tipis. Suplai darah untuk daun telinga berasal dari dua sumber utama yaitu cabang posterior arteri (a) temporal superfisial dan a. aurikularis posterior. Drainase vena (V) yaitu V. retromandibula, V. temporalis superfisial dan $V$. jugularis eksterna. Drainase limfatik melalui kelenjar limfe parotis, mastoid, servikal superior dan infraklavikula node. Flap berdasarkan a. auricularis posterior berguna dalam rekonstruksi telinga karena kedekatan suplai arteri dan juga karena kulit posterior aurikula menyediakan warna yang mirip untuk defek pada telinga. ${ }^{1,2}$

Telinga luar dipersarafi oleh cabang sensorik dari empat saraf kranial. Nervus $(\mathrm{N})$ aurikularis mayor mempersarafi setengah telinga bagian bawah dan sebagian dari daerah preauricular. Nervus aurikulotemporalis mempersarafi permukaan anterior 
daun telinga dan tragus. Nervus oksipitalis minor mempersarafi daerah telinga bagian atas dan mastoid.

Meatus akustikus eksternus dipersarafi oleh n. Arnold, cabang n. vagus. ${ }^{1-3}$

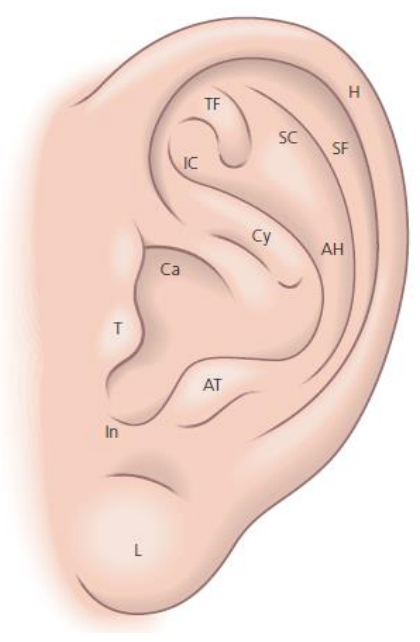

Gambar 1. Anatomi daun telinga: helix $(\mathrm{H})$, antiheliks $(\mathrm{AH})$, cymba concha (Cy), cavum concha (Ca), superior crus (SC), crus inferior (IC), triangular fossa (TF), scafoid fossa (SF), tragus (T), antitragus (A), intertragic notch $(\mathrm{In})$, earlobe $(\mathrm{L}){ }^{1}$

Nomenklatur bagian telinga dalam Gambar 1 penting untuk memahami deskripsi berbagai defek. Aspek estetika pada daun telinga penting dalam rekonstruksi telinga, sebagai penanda untuk ukuran, orientasi dan proporsi komponen normal telinga. ${ }^{1,3}$

Ketinggian telinga biasanya ditentukan oleh landmark sejajar lateral alis dan dasar alar. Lebar dari telinga sekitar $55 \%$ dari panjang telinga. Sumbu telinga membentuk sudut sekitar $15^{0}$ dari bridge hidung. Tepi heliks dipisahkan 1-2 cm dari mastoid dimana jarak meningkat pada bagian kaudal. ${ }^{1,2}$

Kasus-kasus akut penyebab terjadinya defek pada telinga adalah trauma, luka bakar, telinga cauliflower, neoplasma. Pilihan rekonstruksi dari daun telinga dapat diklasifikasikan sebagai berikut ${ }^{1-4}$

- Defek 1/3 atas: flap lokal dari kulit yang berdekatan dapat digunakan untuk menutup defek kecil. Teknik flap advancement V-Y dapat digunakan untuk menutup defek kecil sampai sedang. Defek yang melibatkan heliks dapat direkonstruksi menggunakan flap pedicle berdasarkan arteri auricularis posterior.
- Defek 1/3 tengah: sama seperti di 1/3 atas, defek pada heliks dapat direkonstruksi dengan flap posterior aurikula. Jika defek melibatkan lipatan heliks dan antiheliks sering dibutuhkan kartilago yang diambil dari cangkok tulang iga. flap Dieffenbach adalah flap advancement yang dapat digunakan untuk defek daun telinga 1/3 tengah (Gambar 2).

- Defek 1/3 bawah: bagian lobulus sulit untuk mensimulasikan teknik rekonstruksi. Flap lokal digunakan baik sebagai prosedur tunggal atau dua tahap. Kartilago dapat digunakan untuk memberikan penyangga untuk rekonstruksi lobulus.

- Defek konka: defek parsial konka dapat ditatalaksana menggunakan full thickness skin graft. Trapdoor flap juga dapat digunakan untuk defek konka.

\section{Flap Dieffenbach}

Flap adalah transfer kulit dan jaringan subkutan dengan suplai darah sendiri dan biasanya dilakukan pada daerah sekitar atau dekat dengan defek. Flap dapat diklasifikasikan berdasarkan lokasi, suplai pembuluh darah dan metode perpindahan jaringan. ${ }^{3,5}$

Berdasarkan lokasi, flap kulit lokal melibatkan penggunaan jaringan berbatasan langsung atau dekat dengan defek. Rancangan flap dibedakan menjadi flap pivotal (rotasi, transposisi, interpolasi) dan flap advancement. Flap regional melibatkan penggunaan jaringan dari luar wajah, kulit kepala atau leher dimana pedikel arteri cukup untuk mencapai defek pada wajah. Flap jauh melibatkan jaringan dari lokasi yang jauh sehingga membutuhkan anastomosis pembuluh darah mikrovaskuler (free flap tissue transfer). Flap diklasifikasikan berdasarkan suplai pembuluh darah seperti pembuluh darah random atau aksial. $^{3,5}$

Peter dan Kwan menjelaskan teknik Flap Dieffenbach yang merupakan flap advancement dalam 2 tahap yaitu tahap 1 (perancangan flap) dan tahap 2 (memisahkan flap dan memperbaiki defek sekunder). Pada tahap 1 perkiraan panjang flap sangat penting. Flap setidaknya $2 \mathrm{~mm}$ lebih panjang dari defek. Namun, ketika digunakan untuk merekonstruksi defek rim heliks memerlukan sekitar $4 \mathrm{~mm}$ lebih panjang 
dibanding defek. Flap yang terlalu panjang harus dihindari karena dapat menyebabkan devaskularisasi. Ketebalan jaringan lunak memungkinkan operator untuk menghasilkan flap dengan berbagai ketebalan untuk mencocokkan defek telinga. Flap dapat digulung dan dibuat tebal untuk menciptakan rim heliks atau ditipiskan untuk menghindari perbedaan ketinggian. Penggunaan pedicle yang lebar akan memaksimalkan suplai darah yang tersedia dari pembuluh darah retroaurikula. Ketegangan flap dapat dikurangi dengan immobilisasi telinga ke mastoid dengan jahitan. Balutan kompresi dilakukan dan sebaiknya dipertahankan selama 1 minggu. ${ }^{6}$

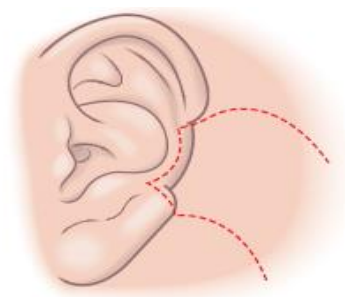

(a)

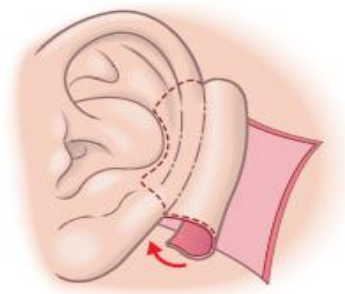

(c)

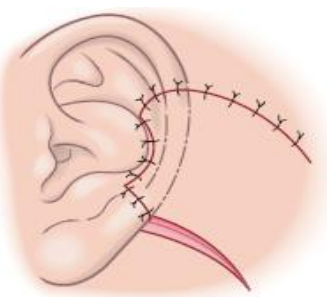

(b)

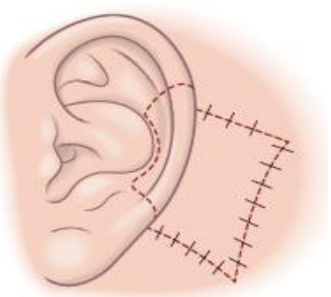

(d)
Gambar 2. Flap Dieffenbach. a. Flap diambil dari kulit posterior aurikular atau mastoid. b. Flap ini digunakan menutup defek. c. Ketika telah terjadi revaskularisasi maka dilakukan operasi pemisahan flap tahap dua. $d$. Flap yang telah dipisah dapat digunakan untuk menutup defek di bagian posterior telinga. ${ }^{1}$

Peter dan Kwan mengatakan pada tahap 2 flap harus dibiarkan setidaknya 2 minggu sebelum memisahkannya dari kulit retroaurikula. Semakin lama tahap kedua dilakukan maka jaringan granulasi akan terjadi pada defek sekunder. Defek sekunder yang kecil $(2 \mathrm{~cm})$ akan menutup sepenuhnya dalam 2 sampai 4 minggu. Jika defek sekunder besar atau jika luka lambat sembuhnya, maka defek ini harus ditutup dengan penjahitan. ${ }^{6}$

\section{Keratosis Seboroik}

Keratosis Seboroik adalah tumor jinak epidermis yang biasanya terdapat pada orang tua. Keratosis seboroik dapat menyebabkan keluhan kosmetik terutama bila timbul pada wajah. Keratosis seboroik (kutil seboroik) biasanya jumlahnya tidak banyak dan ukurannya kecil. Keratosis seboroik banyak terdapat di leher dan anggota badan. Lesi soliter besar sangat jarang. Faktor-faktor yang mungkin berpengaruh dalam etiologi penyakit ini diantaranya paparan sinar ultraviolet, infeksi human papillomavirus, faktor keturunan dan hormon estrogen. Perubahan ke ganas mungkin terjadi tetapi sangat jarang. Gejala yang mungkin dapat terjadi berupa rasa gatal. $^{7-9}$

Pemeriksaan histologi dapat mengkonfirmasi keratosis seboroik. Diagnosis banding keratosis seboroik secara klinis adalah actinic keratosis (solar keratosis or senile keratosis) dan Lentigomaligna (Hutchinson's freckle). ${ }^{9,10}$

Keratosis seboroik dapat ditatalaksana dengan elektro-kacuter, kuretase dan teknik eksisi. Pemeriksaan histopatologi dapat mengkonfirmasi keratosis seboroik. ${ }^{7,8,11}$

\section{KASUS}

Seorang perempuan berusia 48 tahun datang ke poliklinik THT-KL sub bagian Plastik Rekonstruksi RSUP DR. M. Djamil Padang pada tanggal 28 Januari 2016 dengan keluhan utama benjolan kehitaman di telinga kanan yang semakin membesar sejak 5 tahun yang lalu. Sebelumnya benjolan sudah ada sejak 30 tahun yang lalu sebesar biji jagung kemudian semakin lama semakin besar.

Pasien juga merasakan gatal yang hilang timbul pada benjolan di telinga kanan. Penurunan pendengaran tidak ada. Riwayat mudah berdarah pada benjolan tidak ada. Riwayat trauma pada telinga kanan tidak ada. Riwayat telinga sering terpapar sinar matahari tidak ada. Riwayat diabetes melitus tidak ada. Penurunan berat badan tidak ada. Pasien seorang guru dan memakai jilbab sejak 35 tahun yang lalu. 
Pada pemeriksaan fisik didapatkan status generalis dalam batas normal. Tidak didapatkan kelainan pada hidung, tenggorok dan telinga kiri. Pada pemeriksaaan telinga kanan tampak massa berwarna kehitaman berbentuk bulat pada $1 / 3$ medial daun telinga, permukaan tidak rata, tidak mudah berdarah, batas tegas ukuran diameter $3 \mathrm{~cm}$, tinggi $0,2 \mathrm{~cm}$. (Gambar 3). Evaluasi liang telinga lapang, membran timpani utuh, tampak reflek cahaya. Berdasarkan anamnesis dan pemeriksaan fisik pasien didiagnosis tumor aurikula dextra suspek jinak. Pasien direncanakan eksisi tumor dalam anestesi umum.

Hasil pemeriksaan laboratorium Maret 2016 didapatkan hemoglobin $11,3 \mathrm{~g} / \mathrm{dl}$, leukosit $6.050 / \mathrm{mm}^{3}$, trombosit $265.000 / \mathrm{mm}^{3}$, hematokrit $34 \%$, PT 10", APTT 37,3", gula sewaktu $97 \mathrm{mg} / \mathrm{dl}$, ureum $31 \mathrm{mg} / \mathrm{dl}$, kreatinin 0,8 mg/dl, SGOT $29 \mathrm{u} / \mathrm{l}, \quad$ SGPT $17 \mathrm{u} / \mathrm{l}$, dengan simpulan dalam batas normal. Hasil Rontgen thorak didapatkan jantung dan paru dalam batas normal. Hasil toleransi operasi dengan resiko kardiovaskuler, pulmoner, metabolik dan hemostatik ringan.
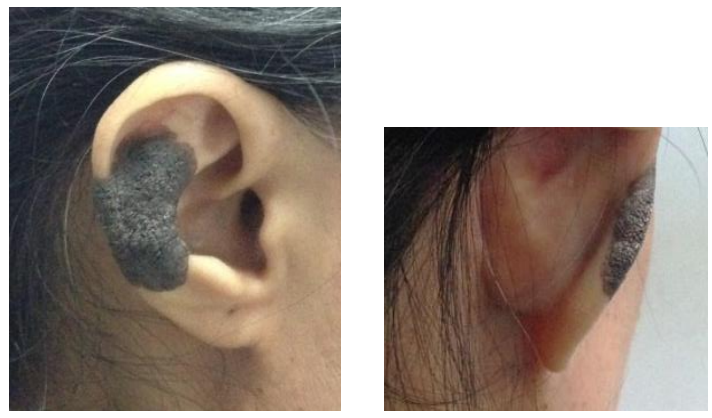

Gambar 3. foto pasien sebelum operasi

Pasien dioperasi tanggal 30 Maret 2016. Pada laporan operasi pasien terlentang diatas meja operasi dalam anestesi umum, dilakukan tindakan aseptik dan antiseptik lapangan operasi dilakukan eksisi $1 \mathrm{~mm}$ dari tumor aurikula, pada saat eksisi tampak tumor tidak melekat dan tidak merusak kartilago. Diameter tumor $3 \mathrm{~cm}$. Pasien direncanakan untuk rekonstruksi defek pada $1 / 3$ medial daun telinga dengan teknik flap Dieffenbach. Dilakukan perancangan design flap pada posterior aurikula dextra. Dilakukan insisi dan undermining pada posterior aurikular dextra hingga flap dapat menutupi defek. Dilakukan penjahitan flap dan dipasang bolster menggunakan kassa. Luka operasi ditutup dengan balut tekan. Operasi selesai. Pasien diberikan terapi sefoperazone $2 \times 1 \mathrm{gr}$ (iv), deksametason $3 \times 5 \mathrm{mg}$ (iv), tramadol $100 \mathrm{mg}$ ampul drip dalam IVFD RL $500 \mathrm{ml}$ setiap 8 jam.

Pada hari pertama setelah operasi (tanggal 1 April 2016) tidak ada nyeri ataupun darah merembes pada telinga dan posterior aurikula. Pasien dilakukan pelepasan balut tekan pada hari ketiga pasca operasi (tanggal 3 April 2016) pada evaluasi (Gambar 4) tampak luka operasi baik, hiperemis, edema minimal, pus tidak ada, jaringan nekrotik tidak ada. Dilakukan pembersihan luka dan luka ditutup kembali dengan kassa. Pasien diperbolehkan pulang, diberikan terapi klindamisin tablet 4x150 mg. Pasien dianjurkan kontrol ke poli THT 3 hari lagi.

Pada kontrol 7 hari pasca operasi (tanggal April 2016) pasien tidak ada keluhan. Pada pemeriksaan fisik didapatkan luka operasi baik, tidak hiperemis namun tampak belum menyatu.

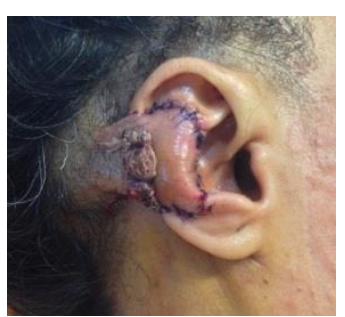

Gambar 4. Tiga hari pasca operasi

Pada kontrol 10 hari pasca operasi (tanggal 11 April 2016) sebagian jahitan dibuka, perdarahan aktif tidak ada. Seluruh jahitan dibuka pada 2 minggu pasca operasi (13 April 2016), tampak flap sudah menyatu (Gambar 5).

Hasil pemeriksaan Patologi Anatomi didapatkan tampak jaringan kulit dilapisi epitel berlapis gepeng yang mengalami akantosis, papilomatosis, hiperkeratosis dengan banyak kista-kista tanduk. Pada lapisan dermis tampak fibrokolagen mengandung kelenjar kelenjar sebasea dan folikel folikel rambut serta kelompokan sel-sel limfosit dan histiosit. Diagnosis keratosis seborroik dan tidak ditemukan tanda-tanda keganasan. Berdasarkan anamnesis, pemeriksaan fisik dan pemeriksaan patologi anatomi pasien didiagnosis pasca eksisi keratosis seboroik pada telinga kanan dengan flap Dieffenbach. 

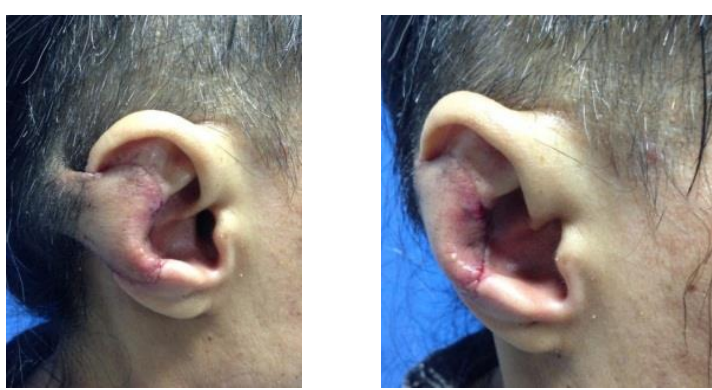

Gambar 5. Kontrol 2 minggu pasca operasi tahap 1

Pasien direncanakan untuk operasi divided flap 3 minggu pasca operasi. Pasien dilakukan pemeriksaan ulang laboratorium dengan hasil hemoglobin $11,5 \mathrm{~g} / \mathrm{dl}$, leukosit $10.160 / \mathrm{mm}^{3}$, trombosit $320.000 / \mathrm{mm}^{3}$, hematokrit $35 \%$, PT 9,7 detik, APTT 34,5 detik, gula sewaktu $120 \mathrm{mg} / \mathrm{dl}$, ureum $20 \mathrm{mg} / \mathrm{dl}$, kreatinin 0,7 mg/dl, SGOT $23 \mathrm{u} / \mathrm{l}$, SGPT $21 \mathrm{u} / \mathrm{l}$, dengan kesimpulan dalam batas normal dan dikonsulkan kembali ke Bagian Penyakit Dalam dengan hasil resiko kardiovaskuler, pulmoner, metabolik, hemostatik ringan.

Tanggal 20 April 2016 Pasien dilakukan operasi divided flap dalam anestesi umum. Dilakukan incisi flap tepat di depan batas aurikula. Dilakukan undermining pada flap yang melekat di aurikula dan dibuang sel lemak untuk mengurangi ketebalan flap, kemudian dilakukan penjahitan flap pada aurikula dan dipasang bolster menggunakan selang nasogastric tube yang telah dipotong seukuran sulkus heliks. Sisa flap pada posterior aurikula di potong sesuai besar luka dan dilakukan penjahitan. Luka operasi ditutup dengan balut tekan. Operasi selesai. Pasien dirawat selama 3 hari dan diberikan terapi pulang klindamicin kapsul 4x150 mg, asam mefenamat tablet 3x500 mg dan dianjurkan kontrol 3 hari lagi.

Pasien kontrol tanggal 28 April 2016 dan dilakukan pelepasan jahitan sebagian. Sedangkan pelepasan seluruh jahitan dilakukan tanggal 02 Mei 2016 didapatkan luka baik, tidak hiperemis, tidak edema, tidak ada pus. Pasien kontrol kembali tanggal 09 Mei 2016 (3 minggu pasca divided flap) dan tanggal 13 Juni 2016 (2 bulan pasca divided flap) dengan tidak ada keluhan. Pasien merasa puas terhadap hasil operasi (gambar 6).

\section{PEMBAHASAN}

Telah dilaporkan seorang perempuan berusia 48 tahun dengan keratosis seboroik yang telah dilakukan eksisi dan flap Dieffenbach pada defek 1/3 medial daun telinga. Pasien datang dengan keluhan utama benjolan kehitaman di telinga kanan yang semakin membesar sejak 5 tahun yang lalu. benjolan sudah ada sejak 30 tahun yang lalu, kadang terasa gatal.

Pada pemeriksaaan telinga kanan tampak benjolan kehitaman berbentuk bulat pada 1/3 medial daun telinga, permukaan tidak rata, tidak mudah berdarah, batas tegas, diameter $3 \mathrm{~cm}$ dan tinggi 0,2 $\mathrm{cm}$. Pasien awalnya didiagnosis tumor aurikula dextra suspek jinak. Kemudian dilakukan pemeriksaan histopatologis dengan hasil keratosis seboroik.
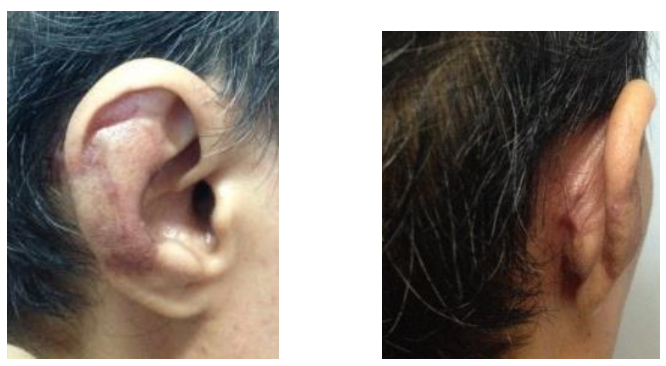

Gambar 6. Foto 2 bulan pasca divided flap (tahap 2)

Hal ini sesuai dengan gejala keratosis seboroik dimana didapatkan lesi jinak yang biasanya jumlahnya hanya beberapa namun dapat menjadi lesi yang besar dan dapat menimbulkan gejala gatal. ${ }^{7,10}$

Bila tidak mengganggu maka keratosis seborroik tidak perlu dilakukan intervensi namun bila menimbulkan keluhan secara kosmetik maka perlu dilakukan operasi eksisi. ${ }^{10,11}$ Permasalahan pada keratosis seboroik yang besar pada bagian wajah adalah adanya defek setelah operasi. Pada pasien ini dilakukan penutupan defek menggunakan teknik flap Dieffenbach.

Teknik flap Dieffenbach atau flap posterior aurikula sangat sesuai untuk defek pada 1/3 medial daun telinga. Flap yang digunakan berasal dari posterior aurikula memberikan warna serta kontur yang cukup sesuai dengan aslinya. ${ }^{1,2,6}$ Monica mengatakan bahwa teknik flap Dieffenbach dapat digunakan untuk defek lebih besar dari $2,5 \mathrm{~cm} .{ }^{12}$ 
Teknik flap Dieffenbach menggunakan 2 tahap operasi yaitu pada tahap pertama dilakukan flap yang berasal dari posterior aurikula dan tahap kedua dilakukan pemisahan flap dan penutupan defek bekas flap. Jarak operasi pertama dan kedua optimalnya 3 minggu karena waktu yang diperlukan bagi flap untuk revaskularisasi. $^{6}$

Bila terdapat rambut pada flap maka dapat dihilangkan dengan beberapa cara seperti dengan mencukur, mencabut, atau dengan menggunakan LASER (Light Amplification by Stimulated Emission of Radiation). Sampai saat ini belum ada cara untuk menjamin rambut tidak tumbuh kembali. ${ }^{13,14}$ Haedersdal dalam penelitiannya menunjukkan bahwa penggunaan LASER lebih menguntungkan dan disukai dibandingkan cara konvensional dan menunjukkan hasil tidak tumbuhnya rambut lebih dari 6 bulan setelah 2-3 kali penyinaran. ${ }^{14}$

Satu hal yang perlu dipersiapkan sebelum operasi adalah adanya kemungkinan tumor mendestruksi atau menempel pada kartilago, sehinggga mungkin diperlukan pengangkatan kartilago dan rekonstruksi baik dengan reduksi atau graft kartilago. Teknik flap dengan reduksi yang dapat digunakan seperti teknik Burrow's triangle, Antia-Buch, Templer. Sedangkan bila defek memerlukan graft kartilago maka dapat dilakukan teknik flap Dieffenbach dengan graft iga, Inferior based transposition flap. ${ }^{15}$

Pada defek yang mengenai hanya rim heliks dapat digunakan Teknik Antia-Buch, ${ }^{15}$ Ear Lobe Based Advancement Flap (ELBAF), ${ }^{16}$ ataupun Posterior aurikular tube flap. ${ }^{17}$

Kerugian menggunakan teknik rekonstruksi dengan reduksi adalah ukuran telinga yang lebih kecil dibandingkan sebelumnya. Komplikasi dari flap diantaranya dapat terjadi perdarahan, hematoma, infeksi, trauma pada struktur disekitarnya, iskemia, nekrosis jaringan, jaringan parut dan deformitas bentuk. $^{5}$

\section{SIMPULAN}

Eksisi tumor daun telinga dapat menimbulkan defek pada telinga yang memerlukan rekonstruksi. Flap Dieffenbach dapat digunakan untuk menutup defek pada 1/3 medial daun telinga dengan hasil yang sangat baik dan memuaskan.

\section{DAFTAR PUSTAKA}

1. Lok HY, Rajive MJ. Dalam: John C. W, Ralph W. $\mathrm{G}$, editor (penyunting). Stell \& Maran's textbook of head and neck surgery and oncology. Edisi ke-5, London: Hodder Arnold; 2012.hlm.1014-26.

2. Richard Y, Matthew JT. Plastic surgery of the ear. SRPS. 2011;11;1-45.

3. Vasilios KT. Cutaneous flap in head and neck reconstruction. New York: Springer; 2014.hlm.30112.

4. Satoshi U, Katsunori $Y$, Yosuke W, Makoto M, Yuko H. Partial reconstruction of auricle. Hirosaki Med J. 2016;66:99-104

5. Brian J. Local cutaneous flap and grafts. Dalam: Bailey BJ, Johnson JT, Newlands SD, editor (penyunting). Head and neck surgery otolaryngology. Edisi ke-5. Philadelphia: Lippincot William \& Wilkins; 2014.hlm.2797-822.

6. Peter K, Kwan SL. Retroauricular cutaneus advancement flap. AFP. 2012;41(8):601-2.

7. Banavasi SG, Kamath DS, Permi SH. Seborrhoeic keratosis; a rare cause of conductive deafness. JCDR. 2012;6(5):913-4.

8. Karen JS. Management of benign facial lesion. Dalam: Brian J, Bailey BJ, Johnson JT, Newlands SD, editor (penyunting). Head and neck surgery otolaryngology. Edisi ke-5, Philadelphia: Lippincot William \& Wilkins; 2014.hlm.3212-28.

9. Mundra RK, Agrawal R, Sinha R. A rare interesting case of seborrhoeic keratosis of pinna. Case Reports in Clinical Medicine. 2013;2(8):463-5.

10. Kiran N, Aderesh S, Nitin LM. A rare case of large seborrheic keratosis of the pinna. CIBTech, 2014;3(3):9-10.

11. Angela JW, Klaus JB. Tumor of the epidermis. Dalam: Klaus JB, editor (penyunting). Dermatopathology. Edisi ke-2. Philadephia: Saunders Elseviere Inc; 2016.hlm.342-8.

12. Monica R.O. Partial reconstruction of the external ear after a trauma- simple and efficient technique. Braz J. Otorhinolaryngol, 2010;76(1):7-13. 
13. Helen RB. Alternative method of hair removal. Dalam: Sherry G, editor (penyunting). Milady's hair removal techniques: a comprehensive manual. Thompson learning Inc. 2004.hlm.65-150.

14. Haedersdal M, Wulf HC. Evidence base review of hair removal using lasers and light sources. JEADV. 2006;20:9-20.

15. Weerda H. Auricular region. Reconstructive facial plastic surgery: a problem solving manual. Edisi ke-2. Thieme. 2014hlm.135-206.
16. Isaac Z, Sebastian C, Niels $H$, Christine $F$, Christine E, Demetris S, et al. The arterial blood supply of the helical rim and the earlobe-based advancement flap (ELBAF): a new strategy for reconstructions of helical rim defect. JPRAS. 2015; 68: $56-62$.

17. Aleksandra I, Edward L, Boguslaw A, Tomasz Z. Result of aurikular helical rim reconstruction with post aurikular tube flap. Polski. 2016;88:32-7. 